\title{
In vitro study on the influence of the light polymerization technique and appliance on the bond strength of intra-radicular posts
}

\section{Estudo in vitro da influência da técnica e do aparelho de fotopolimerização sobre a resistência de união de pinos intra- radiculares}

\author{
Denis Yudi NAGASE \\ PhD Degree Student - Department of Restorative Dentistry - University of São Paulo - SP - Brazil.
}

\section{Susana MORIMOTO}

PhD - Professor - Department of Bio-Odontology - Ibirapuera University - SP - Brazil.

\section{Carlos Martins AGRA}

PhD - Professor - Department of Bio-Odontology - Ibirapuera University - SP - Brazil.

\section{Glauco Fioranelli VIEIRA}

Margareth ODA

PhD - Associated Professor - Department of Restorative Dentistry - University of São Paulo - SP Brazil.

\begin{abstract}
The purpose of this study is to verify the influence of light curing type on retention force of direct technique and directindirect technique.Forty bovine single root teeth with $12 \mathrm{~mm}$ length were used in this study. Roots were endodontically treated and randomly divided into four groups according to the light curing unit and the technique used: group HD (direct technique, halogen lamp), group LD (direct technique, LED), group HI (direct-indirect technique, halogen lamp), group LI (direct-indirect technique, LED). Retention force was determined using a Universal Testing Machine (Instron). All data were analyzed using one-way analysis of variance (ANOVA) and Tukey's test. After the test, failure was examined and classified according to the fracture place: post/ resin; resin/dentin; mix. Group HI (246.05N \pm 29.51$)$ and LI $(241.60 \mathrm{~N} \pm$ $28.95)$ did not show difference statistically but presented higher retention force than group HD $(142.30 \mathrm{~N} \pm 25.60)$ and $\mathrm{LD}(178.56 \mathrm{~N} \pm 25.67)$. Most of fracture occurred in interface between dentin/resin. Based on the obtained results, it was concluded that adhesive cementation technique influenced in the retention of glass fiber post.
\end{abstract}

\section{KeYWORDS:}

Fiber post; retention force; direct method; direct-indirect method; halogen lamp; LED.

\section{INTRODUCTION}

In the case of crown restoration of endodontically treated teeth, a core buildup is necessary in the remaining tooth structure. Restoration is supported by a cast or prefabricated post and core system [1]. Metal posts are too strong and rigid in the tooth, resulting in root fracture. This problem is caused by a difference in elastic modulus between dentin and post [2].

The introduction of fiber post systems has provided a new option for restoration of endodontically treated teeth. These posts are composed of unidirectional carbon or glass fibers embedded in a resin matrix [3]. They have two important characteristics; namely their elastic modulus is similar to that of dentin, and their neutral color is an esthetic quality. These properties make them good alternatives to replace metal posts [4,5].

To build up fiber post in the root canal, resin materials have been used until now. Resin cement and post resin undergo polymerization shrinkage. As a result, a gap forms between dentin and resin material, and this may reduce post restoration retention. Three 
principal techniques are used to fabricate FRC (fiberreinforced composite) post-and-cores: direct, directindirect, and indirect techniques. Which of these systems results in the best retention force of a FRC post in a root canal has not yet been systematically demonstrated.

Over the last few years, the light polymerization technique has advanced with the introduction of halogen lamp and LED light polymerizing appliances. The latter has presented inferior results as regards surface microhardness and polymerization depth when compared with those of the halogen lamp light polymerizer units. [6,7]. Nevertheless, LED has increasingly been used by dentists, as it presents advantages such as low heat production, compact size and longer useful life than the halogen lamp [8].

The aim of this study was to verify LED influence on retention strength of intraradicular posts, both in the direct and direct-indirect techniques.

\section{Material an Method}

\section{Root Preparation}

Intact bovine incisors and canine were cleaned and stored in water at $4{ }^{\circ} \mathrm{C}$. The crowns of the teeth were sectioned below cement enamel junction using a diamond disk with water coolant and low-speed hand piece. The cut was made perpendicular to the long axis of the tooth. Forty root canals up to $2.0 \mathrm{~mm}$ in diameter were selected.

The roots were endodontically instrumented with \#35 file at a length of $1 \mathrm{~mm}$ short of the apex. After this, the prepared root canal was filled with gutta percha. A \#2 Peeso Reamer was used to remove 7 $\mathrm{mm}$ of gutta-percha. The canal was irrigated with distilled water and dried with paper points. Roots were fixed with self-polymerizing resin (Acrylic Resin, Jet Classico, Brazil) in an acrylic pipe $(17 \mathrm{~mm}$ in diameter, $30 \mathrm{~mm}$ high). They were centered in the acrylic pipe and $2 \mathrm{~mm}$ of cervical area were kept uncovered.

FibreKor ${ }^{\circledR}$ post (Jeneric/Pentron Inc., USA), namely FK post, which was $1.25 \mathrm{~mm}$ in diameter was used in this study. The posts were cemented in the endodontically treated roots with resin cement (3M ESPE RelyX CRA, 3M, Brasil) by direct or directindirect technique. They were light polymerized using a halogen lamp or LED. Table 4.1 lists four combination of fabrication technique and light curing unit $(n=10)$.
TABle 1 - Groups Were divided ACcording TO THE METHOD AND THE LIGHT POLYMERIZING appliance used. The endodontically tReated TEETH WERE RANDOMLY DIVIDED INTO 4 GROUPS WITH 10 SAMPLES EACH

\begin{tabular}{c|c|c}
\hline Groups $(n=10)$ & Light Curing Unit & Technique \\
\hline HD & Halogen & direct \\
\hline LD & Led & direct \\
\hline HI & Halogen & direct-indirect \\
\hline LI & Led & direct-indirect \\
\hline
\end{tabular}

\section{Group HD}

Root canal walls were etched with $37 \%$ phosphoric acid for $15 \mathrm{~s}$ and washed with water according to manufacturer's instruction. Excess water was removed with paper points, leaving the root canal moist. An activator was applied to the root canal using a microbrush. Next, primer was applied and a catalyst (AdperTM Scotchbond Multi-Purpose Plus, 3M ESPE, Brasil ). The same quantity of dual polymerization type resin cement base and catalyst (RelyX CRA, 3M, Brasil) were mixed on a paper pad and delivered into the root canal with a lentulo spiral using a low-speed handpiece. FK post was then placed in the root canal with finger pressure. Excess resin cement was removed, and cement was lightpolymerized with a halogen lamp (Astralis 10, Ivoclar Vivadent, Brazil, $1200 \mathrm{~mW} / \mathrm{cm}^{2}, 400-510 \mathrm{~nm}$ ) for 40 s.

\section{Group LD}

The procedure was the same as used in group HD, but a LED light curing unit (Radii, SDI, Brazil, $1200 \mathrm{~mW} / \mathrm{cm}^{2}, 440 \mathrm{~nm}-480 \mathrm{~nm}$ ) was used to light polymerize the resin material.

\section{Group HI}

A gel hydrosolubilit agent was applied to root canal walls. The same quantity of resin cement base and catalyst (RelyX CRA, 3M, Brazil) were mixed on a paper pad and delivered into the root canal with a lentulo spiral. The FK post was then placed in the root canal with finger pressure and light-polymerized for 10s. After this, pre-light polymerized post-and-core was removed from the root canal and light-polymerized 
a second time for 30 s. Root canal walls were etched with $37 \%$ phosphoric acid for 15 s and washed with water according to manufacturer's instruction. Excess water was removed with paper points, leaving the root canal moist. An activator was applied to the root canal using a microbrush. Next, primer was applied and a catalyst (AdperTM Scothbond Multi-Purpose Plus, 3M ESPE, Brasil ). The same quantity of dual polymerizing type resin cement base and catalyst (RelyX CRA, 3M, Brasil) were mixed on a paper pad and delivered into the root canal with a lentulo spiral using a low-speed handpiece. The FK post was then placed in the root canal with finger pressure. Excess resin cement was removed, and the cement was light polymerized with a halogen lamp (Astralis 10, Ivoclar Vivadent, Brazil, $1200 \mathrm{~mW} / \mathrm{cm}^{2}, 400-510 \mathrm{~nm}$ ) for 40s.

\section{Group LI}

The procedure was the same as used in Group 3, but a LED light curing unit (Radii, SDI, Brazil, $1200 \mathrm{~mW} / \mathrm{cm}^{2}, 440 \mathrm{~nm}-480 \mathrm{~nm}$ ) was used to light polymerize the resin material.

\section{Bond Strength Evaluation}

After sample preparation, a mini acrylic pipe was fixed onto the coronal section of the post using a light polymerized resin. Specimens were mounted on an acrylic pipe with a self-polymerizng resin and stored in a $100 \%$ humidity medium $\left(37^{\circ} \mathrm{C}\right)$ for 24 h. Retention force was determined using a universal testing machine (Mini Instron 4442, Canton, MA, USA) at a crosshead speed of $0.5 \mathrm{~mm} / \mathrm{min}$. The load cell was set at $500 \mathrm{~N}$.

After the tensile test, fracture sites were observed with a microscope (Olympus, SZ-PT, Japan) and classified as resin/dentin, resin/post or mixed fractures (both of them)

\section{Statistical ANALYSis}

All data were statistically analyzed using analysis of variance (ANOVA) supplemented with Tukey's test at significance level of $\mathrm{p}<0.05$

\section{Results}

Table 2 lists retention forces of post-and-cores. The values for the direct-indirect technique were higher than those of the direct technique. In the direct technique groups (HD, LD), LED presented a higher retention force than the halogen lamp.

TABLE 2 - RETENTION FORCES OF POSTS AND CORES

\begin{tabular}{c|c|c}
\hline Group & Mean (N) & $\begin{array}{c}\text { Standard } \\
\text { Deviation }\end{array}$ \\
\hline HD & 142,30 & $( \pm 25,60)^{\mathrm{a}}$ \\
\hline LD & 178,56 & $( \pm 25,67)^{\mathrm{b}}$ \\
\hline HI & 246,05 & $( \pm 29,51)^{\mathrm{c}}$ \\
\hline LI & 241,60 & $( \pm 28,95)^{\mathrm{c}}$ \\
\hline
\end{tabular}

Different Letters $(a, b, c, d)$ indicate statistical differences among the groups based on Tukey's test

Figures 1 and 2 show typical photographs of the fracture sites: (a) Post/Resin indicates an interface between post and resin cement; (b) Resin/Dentin indicates an interface between resin cement and dentin; and (c) Mixed indicates both Resin/Dentin and Post/Resin fractures. Table 3 lists fracture sites classification in each group. In all groups, the fractures occurred mainly at the Post/Resin interface $(80 \%, 100 \%, 90 \%$ e $100 \%$ respectively). Other fractures occurred in mixture mode (resin/post fractures occurred only in the apical third).

TABle 3 - Fracture classification after the RETENTION TEST

\begin{tabular}{c|c|c|c}
\hline Group & Resin/Dentin & Dowel/Resin & Mix \\
\hline HD & 8 & 0 & 2 \\
\hline LD & 10 & 0 & 0 \\
\hline HI & 9 & 0 & 1 \\
\hline LI & 10 & 0 & 0 \\
\hline
\end{tabular}

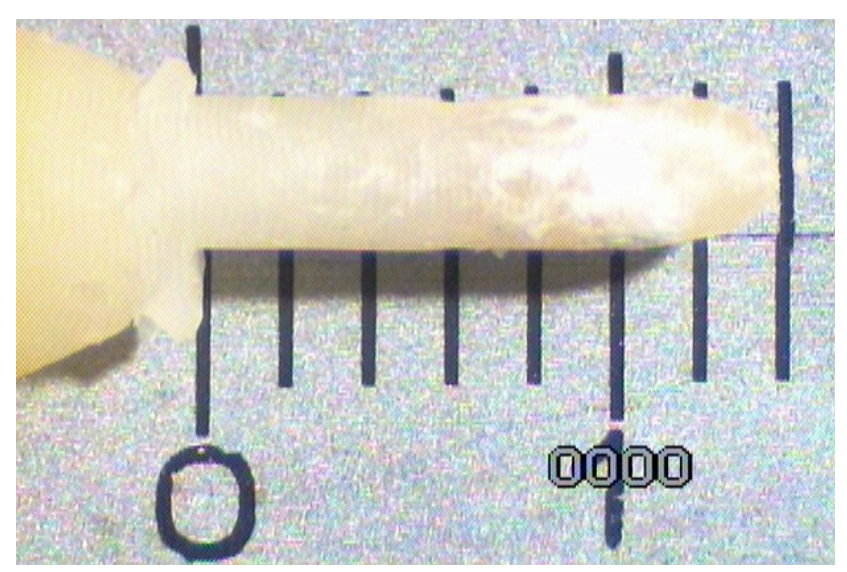

Figure 1 - Failure occurred at the resin/dentin interface. 


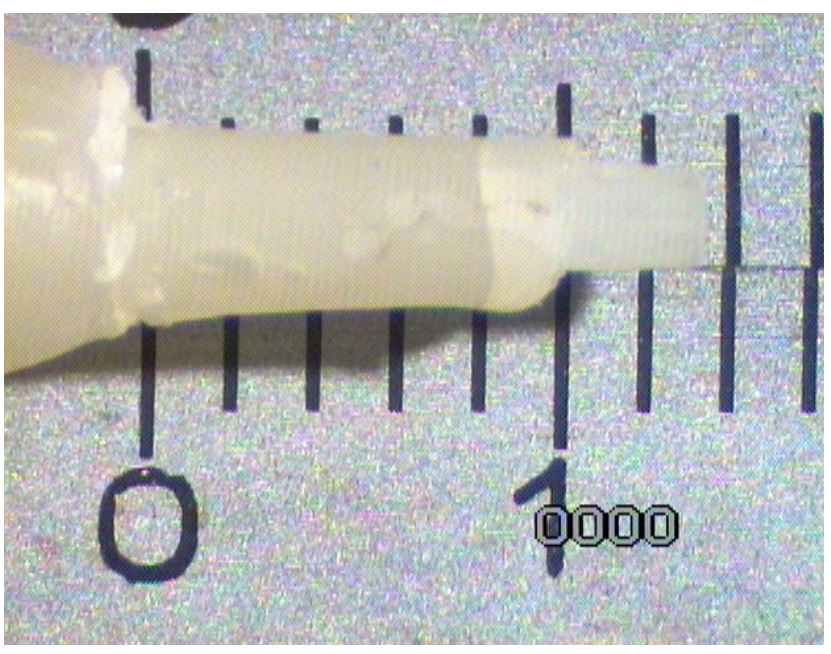

Figure 2 - Mixed failure (resin/dentin and resin/dowel)

\section{Discussion}

Prefabricatedglassfiberpostshavebeenincreasingly used in the fabrication of cores for endodontically treated teeth. This is because its modulus of elasticity is close to that of dentin, in addition to a favorable esthetic factor [4,5]. Manufacturer recommends two core fabrication methods: the direct and the directindirect techniques. Moreover, it is still not clear which light polymerizing appliance (Halogen lamp or LED) would be most favorable for cementation of fiber post systems. In this study, the influence of core fabrication technique and light polymerization appliance on the retention of prefabricated posts was evaluated. Two samples from HD and one from LD presented fracture between resinous material and post at the apex of the core, leaving a material remainder inside the canal. This indicated that the failure was a combination of adhesive and cohesive failure between post and resin. One could say, therefore, that the bond between post and resin was not satisfactory, or the polymerization depth was insufficient. In a study conducted a by Mallmann et al. [9], this type of failure occurred with the use of chemical adhesive Scotch Bond Multi Purpose (3M ESPE, Brazil), as the bond between cement and dentin was stronger than that between post and cement. This cannot be considered a reference, as it is believed that the bond of post and cement is stronger than that of cement and dentin. This may have occurred due to high chemical compatibility of the adhesive Scotch Bond Multi Purpose with the resinous cement Rely X. In another study on post retention, Schmage et al. [10], also obtained some results in which the fracture occurred at the post/cement interface. According to the author, this occurred due to a high bond strength obtained by dual adhesive to dentin, which would make post/ cement interface fracture first. To Sadek et al. [11], the bond between post and resin is generally stronger than that of resin to dentin due to mechanical interlocking and chemical bond that occurs between them.

Polymerization depth is related to light intensity, exposure time as well as the resin shade inadequate resin polymerization may result in a low degree of polymerization in the apical third of the core, and this could result in a cohesive failure of the resin in this region $[12,13]$. In other words, the core fabricated by the direct method may have fractured in resinous cement region due to insufficient light intensity during its polymerization. Moreover, the composition of the resinous cement and the polymerization method may affect its polymerization shrinkage. Although a resinous cement containing a low quantity of load has a diminished viscosity, which facilitates clinical procedure and improves its adaptation to the post, it has greater polymerization shrinkage than a cement containing a high quantity of load $[11,14]$. Consequently, it would have lower retention strength.

In all groups (HD halogen direct, LD LED direct, HI halogen direct-indirect, LI LED direct- indirect), the majority of the fractures, $80 \%, 100 \%, 90 \%$ and $100 \%$ respectively, occurred at the resin/dentin interface. In another study [15], the bond between post/cement and cement/dentin interfaces was separately evaluated, and it was demonstrated that the bond between post and cement is stronger than the bond between cement and dentin. Many studies have demonstrated that the bond with adhesive system to root dentin is complex due to the difficulty of light polymerization inside the canal $[9,16,17]$ and the high $C$ factor [9,12,17-19]. Polymerization shrinkage causes a stress in the resin/ dentin interface resulting in the weakening of the bond interface and gap formation [10,11]. To some authors [9,17], in spite of the advancement in bonding to dental structure, a study must be conducted to minimize polymerization shrinkage in the resinous material.

Taking into consideration resin polymerization shrinkage, one could also explain the difference in the retention strength between the two methods. In the direct-indirect method a higher retention strength was obtained than in the direct method; that is, Group HI presented a higher retention strength than Group HD, and Group LI higher than Group LD. This difference occurred because direct-indirect method presents better adaptation of the core to the root canal [20,21]. In this method, a greater part of the resin polymerization shrinkage occurs outside 
the root canal, and when the core is re-inserted in the canal, the bond with resinous cement occurs only between core and dentin. On the other hand, in direct method, polymerization shrinkage occurs inside the root canal, thus there is a thinner layer of resinous cement in the direct-indirect method. Therefore, the presence of microporosity is diminished and there is less polymerization shrinkage [22]. Some authors $[23,24]$ have observed a formation of bubbles when they used resinous cement as filling material. The bubbles may result in fracture points that propagate and could cause the post to fracture. In direct-indirect method, errors that occur during the procedure could be corrected by resinous cement. The difference in retention between the 2 methods could be attributed to a lower amount of polymerization shrinkage and less presence of bubbles in resinous cement in directindirect method [16,17].

Statistically significant difference was verified among Groups 1,2,3; but not between Groups 3 and 4. This means that there was an influence of the type of lamp used. This can be explained by the fact that LED light presents a higher power $\left(1200 \mathrm{~mW} / \mathrm{cm}^{2}\right)$ than Halogen lamp $\left(1200 \mathrm{~mW} / \mathrm{cm}^{2}\right)$, therefore, polymerization depth of filling material is greater with LED. The exposure time to light and its intensity determine mechanical properties of the resin composite. The light goes through it, being absorbed and dispersed, attenuating and reducing the effect of the light on resin polymerization $[13,25,26]$. The efficacy of light depends on total energy; that is, intensity and time are important factors. For adequate polymerization in a short space of time, high light intensity is necessary. High light intensity results in a high polymerization shrinkage stress at the restoration interface, capable of generating microleakage [13,27-29]. Another important factor is the degree of resin hardness. Surface hardness is greater than that of the deeper region. This occurs due to the fact that polymerization depth is directly related to resin thickness, and that is influenced by light intensity and exposure time [13,30,31]. The light intensity determines the degree of resin hardness; that is, a low light intensity will result in a material with a lower degree of hardness [13]. Moreover, the wavelength of the Halogen light appliance, Astralis, ranges between 400 - $510 \mathrm{~nm}$, differing from Radii LED appliance, which has narrower range of light spectrum (440 nm - $480 \mathrm{~nm}$ ), closer to sensitive peak of the photoinitiator Camphoroquinone, that is $465 \mathrm{~nm}[8,12]$.

In direct method, this difference in power had an effect on posts retention, but in the direct-indirect method, this factor was not relevant, since material polymerization occurs outside the root, and therefore does not depend on polymerization depth. Thereby similarity in the results of Groups 3 and 4 can be explained.

A study conducted by Oto et al. [32] verified that, even in dual resinous material, mechanical properties are better in the coronal regions than in the apical portions of roots. This is due to a reduction in light energy as the region becomes deeper, which may result in a reduction in the bond strength of the region.

Some studies have reported that mechanical properties and dentin structure vary according to the region. In the cervical third of the root there is a larger quantity of dentinal tubules than there is in the apical region, and tubule diameters diminish as they approach the apical region $[33,34,17]$. Studies conducted by Foxton et al. [35] and Mallmann et al. [36] affirmed that the bond in cervical and middle thirds is stronger than it is in apical third. Nevertheless, to some authors [37,38], mechanical strength does not vary according to the root dentin region, and in the case of self-etching adhesives, the bond strength is not influenced by the depth of dentin or by the density of the number of tubules. Thus, one could say that the most important factor for bonding to root dentin would be the mechanical properties of the bonding agent, which could improve with adequate polymerization $[37,39]$.

In a study carried out by Aksormuang et al. [37], who used a self-etching adhesive to evaluate the bond of glass fiber posts with various exposure times to light from a photopolymerizing appliance, it was verified that with an increase in light polymerization time they achieved a bond in the apical region without significant difference from that in the coronal region.

Statistical differences were significant among the groups of this study. Therefore, technique used is of extreme importance in the retention of glass fiber posts.

\section{Conclusion}

Based on the results obtained with the methodology used, it was concluded that adhesive cementation technique and light curing unit have an influence on glass fiber posts retention, and the best results were obtained with direct-indirect technique and LED. 


\section{Resumo}

O objetivo deste estudo foi avaliar a influência do tipo de luz sobre força de adesão de pinos feitos pela técnica direta ou indireta. Quarenta dentes bovinos unirradiculares com 12 milímetros de comprimento foram utilizadas neste estudo. As raízes foram tratadas endodonticamente e divididas aleatoriamente em quatro grupos de acordo com a unidade de fotoativação e técnica utilizada: grupo 1 (técnica direta, lâmpada halógena), grupo 2 (técnica direta, LED), grupo 3 (técnica direta indireta, lâmpada halógena ), grupo 4 (técnica direta indireta, LED). A força de retenção foi determinada utilizando-se uma máquina universal de ensaios (Instron). Todos os dados foram analisados pela análise de variância (ANOVA) e teste de Tukey. Após o teste, as falhas foram analisadas e classificadas de acordo com o local de fratura: pino / resina; resina / dentina ou mista. Os Grupos $3(246,05 \mathrm{~N} \pm 29,51)$ e $4(241,60 \mathrm{~N} \pm 28,95)$ não apresentaram diferenças estatísticas entre si, mas apresentou maior força de retenção que os grupos $1(142,30 \mathrm{~N} \pm 25,60)$ e $2(178,56 \pm 25,67 \mathrm{~N})$. A maioria das fraturas ocorreu na interface entre a dentina / resina. Com base nos resultados obtidos, concluiu-se que a técnica de cimentação adesiva influenciou na retenção dos pinos de fibra de vidro.

\section{Palavras-chave:}

Pino de fibra; força de retenção; método direto; método direto-indireto; lâmpada halógena; LED.

\section{REFERENCES}

1. Christensen G. Posts and core: states of the art. J Am Dental Associ 1998;129(1):96-7.

2. Mannocci F, Innocenti M, Ferrari M, Watson TF. Confocal and scanning electron microscopic study of teeth restored with fiber post, metal post, and composite resin. J Endod 1999;25(12):789-94.

3. Perdigao J, Villar A. Use of a tooth-colored post for anterior restorations. Northwest Dent 2002;81(6):13-7.

4. Akkayan B, Gulmez T. Resistance to fracture of endodontically treated teeth restored with different post systems. J Prosthet Dent 2002;87(4):431-7

5. Duret B, Duret F, Reynaud M. Long-life physical property preservation and post endodontic rehabilitation with the Composipost. Compend Contin Educ Dent Suppl 1996;(20):S50-6

6. Aravamudhan K, Rakowski D, Fan PL. Variation of depth of cure and intensity with distance using LED curing lights. Dent Mater. 2006 Nov;22(11):988-94.

7. Cefaly DF, Ferrarezi GA, Tapety CM, Lauris JR, Navarro MF. Microhardness of resin-based materials polymerized with LED and halogen curing units.

8. Braz Dent J 2005;16(2):98-102.

9. Polydorou O, Manolakis A, Hellwig E, Hahn P. Evaluation of the curing depth of two translucent composite materials using a halogen and two LED curing units. Clin Oral Investig. 2008 Mar;12(1):45-51.

10. Mallmann A, Jacques LB, Valandro LF, Muench A. Microtensile bond strength of photoactivated and autopolymerized adhesive systems to root dentin using translucent and opaque fiber-reinforced composite posts. J Prosthet Dent 2007 Mar;97(3):165-72.

11. Schmage P, Pfeiffer P, Pinto E, Platzer U, Nergiz I. Influence of oversized dowel space preparation on the bond strengths of FRC posts. Oper Dent 2009 Jan-Feb;34(1):93-101.

12. Sadek FT, Monticelli F, Goracci C, Tay FR, Cardoso PE, Ferrari $\mathrm{M}$. Bond strength performance of different resin composites used as core materials around fiber posts. Dent Mater 2007 Jan;23(1):95-9.

13. Cunha LG, Alonso RC, Neves AC, de Goes MF, Ferracane JL, Sinhoreti MA. Degree of conversion and contraction stress development of a resin composite irradiated using halogen and LED at two C-factor levels. Oper Dent 2009
Jan-Feb;34(1):24-31.

14. Visvanathan A, Ilie N, Hickel R, Kunzelmann KH. The influence of curing times and light curing methods on the polymerization shrinkage stress of a shrinkage-optimized composite with hybrid-type prepolymer fillers. Dent Mater 2007 Jul;23(7):777-84.

15. Condon JR, Ferracane JL. Assessing the effect of composite formulation on polymerization stress. J Am Dent Assoc 2000;131(4):497-503.

16. Boschian Pest L, Cavalli G, Bertani P, Gagliani M. Adhesive post-endodontic restorations with fiber posts: push-out tests and SEM observations. Dent Mater. 2002 Dec;18(8):596-602.

17. Valandro LF, Ozcan M, Bottino MC, Bottino MA, Scotti R, Bona $\mathrm{AD}$. Bond strength of a resin cement to high-alumina and zirconia-reinforced ceramics: the effect of surface conditioning. J Adhes Dent 2006 Jun;8(3):175-81.

18. Mumcu E, Erdemir U, Topcu FT. Comparison of micro pushout bond strengths of two fiber posts luted using simplified adhesive approaches. Dent Mater J. 2010 May;29(3):286-96. Epub 2010 May 20.

19. Jongsma LA, Bolhuis PB, Pallav P, Feilzer AJ, Kleverlaan CJ. Benefits of a two-step cementation procedure for prefabricated fiber posts. J Adhes Dent. 2010 Feb;12(1):55-62.

20. Albashaireh ZS, Ghazal M, Kern M. Effects of endodontic post surface treatment, dentin conditioning, and artificial aging on the retention of glass fiber-reinforced composite resin posts. J Prosthet Dent. 2010 Jan;103(1):31-9.

21. Nagase DY, Takemoto S, Hattori M, Yoshinari M, Kawada $\mathrm{E}$, Oda Y. Influence of fabrication techniques on retention force of fiber-reinforced composite posts. Dent Mater J 2005 Jun;24(2):280-5.

22. Nagase DY, Matos AB. Influência de duas técnicas de cimentação adesiva na retenção de pinos intra-radiculares de fibra de vidro. Rev Inst Ciênc Saúde 2007;25(4):437-41.

23. Valandro LF, Filho OD, Valera MC, de Araujo MA. The effect of adhesive systems on the pullout strength of a fiberglass-reinforced composite post system in bovine teeth. J Adhes Dent 2005 Winter;7(4):331-6.

24. Vichi A, Vano M, Ferrari M. The effect of different storage conditions and duration on the fracture strength of three types of translucent fiber posts. Dent Mater 2008 Jun;24(6):832-8.

25. Watzke R, Blunck U, Frankenberger R, Naumann M. Interface homogeneity of adhesively luted glass fiber posts. Dent Mater 2008 Nov;24(11):1512-7. 
26. Lindberg A, Peutzfeldt A, van Dijken JW. Effect of power density of curing unit, exposure duration, and light guide distance on composite depth of cure. Clin Oral Investig. 2005 Jun;9(2):71-6.

27. Vargas MA, Cobb DS, Schmit JL. Polymerization of composite resins: argon laser vs conventional light. Oper Dent 1998 Mar-Apr;23(2):87-93.

28. Calheiros FC, Kawano Y, Stansbury JW, Braga RR. Influence of radiant exposure on contraction stress, degree of conversion and mechanical properties of resin composites. Dent Mater. 2006 Sep;22(9):799-803.

29. Dewaele M, Asmussen E, Peutzfeldt A, Munksgaard EC, Benetti AR, Finné G, et al. Influence of curing protocol on selected properties of light-curing polymers: Degree of conversion, volume contraction, elastic modulus, and glass transition temperature. Dent Mater 2009 Dec;25(12):1576-84.

30. Peutzfeldt A, Asmussen E. Resin composite properties and energy density of light cure. J Dent Res. 2005 Jul;84(7):65962 .

31. Sobrinho LC, Goes MF, Consani S, Sinhoreti MA, Knowles JC. Correlation between light intensity and exposure time on the hardness of composite resin. J Mater Sci Mater Med 2000 Jun;11(6):361-4.

32. Paula AB, Tango RN, Sinhoreti MA, Alves MC, PuppinRontani RM. Effect of thickness of indirect restoration and distance from the light-curing unit tip on the hardness of a dual-cured resin cement. Braz Dent J. 2010;21(2):117-22.

33. Oto T, Yasuda G, Tsubota K, Kurokawa H, Miyazaki M, Platt JA. Influence of power density on polymerization behavior and bond strengths of dual-cured resin direct core foundation systems. Oper Dent 2009 Mar-Apr;34(2):192-9.

34. Inoue $\mathrm{T}$, Saito $\mathrm{M}$, Yamamoto $\mathrm{M}$, Debari $\mathrm{K}$, Kou $\mathrm{K}$, Nishimura F, et al. Comparison of nanohardness between coronal and radicular intertubular dentin. Dent Mater J 2009 May;28(3):295-300.
35. Mannocci F, Pilecki P, Bertelli E, Watson TF. Density of dentinal tubules affects the tensile strength of root dentin. Dent Mater 2004 Mar;20(3):293-6.

36. Foxton RM, Nakajima M, Tagami J, Miura H. Density of dentinal tubules affects the tensile strength of root dentin. Dent Mater 2004 Mar;20(3):293-6.

37. Mallmann A, Jacques LB, Valandro LF, Mathias P, Muench A. Microtensile bond strength of light- and self-cured adhesive systems to intraradicular dentin using a translucent fiber post. Oper Dent 2005 Jul-Aug;30(4):500-6.

38. Aksornmuang J, Nakajima M, Panyayong W, Tagami J. Effects of photocuring strategy on bonding of dual-cure onestep self-etch adhesive to root canal dentin. Dent Mater J 2009 Mar;28(2):133-41.

39. Liu J, Hattori M, Hasegawa K, Yoshinari M, Kawada E, Oda Y. Effect of tubule orientation and dentin location on the microtensile strength of bovine root dentin. Dent Mater J. 2002 Jun;21(2):73-82.

40. Takahashi A, Sato Y, Uno S, Pereira PN, Sano H. Effects of mechanical properties of adhesive resins on bond strength to dentin. Dent Mater 2002 May;18(3):263-8.

Received: 03/05/2012 Accepted: 04/09/2012

Corresponding author: Denis Y. Nagase Departamento de Dentistica Faculdade de Odontologia - USP Av. Prof. Lineu Prestes 2227 Sao Paulo - SP - Brazil - 05508-000 dynagase@usp.br 